\title{
Analysis of the Relationship of Noise Exposure and Hearing Loss in PPSU Workers in North Jakarta
}

\author{
Nur Asniati Djaali ${ }^{1,}$ ", Sari Alia Putri ${ }^{1}$, Denny Lyus Sihite ${ }^{2}$, Ajeng Tias Endarti ${ }^{1}$, \\ Sutanto Priyo Hastono ${ }^{2}$, Hasnawati Amqam ${ }^{3}$ \\ ${ }^{1}$ Faculty of Health, Mohammad Husni Thamrin University, Jakarta, Indonesia \\ ${ }^{2}$ Faculty of Pubilc Health, Indonesia University, Depok, West Java \\ ${ }^{3}$ Faculty of Pubilc Health, Hasanuddin University, Makassar, South East Sulawesi \\ Email address: \\ nurdjaali@gmail.com (N. A. Djaali), sarialiaputri9@gmail.com (S. A. Putri),lppmumht@gmail.com (D. L. Sihite), \\ ajengtias@gmail.com (A. T. Endarti),sutantopriyohastono@gmail.com (S. P. Hastono), nana_azzahra@yahoo.com (H. Amqam) \\ *Corresponding author
}

\section{To cite this article:}

Nur Asniati Djaali, Sari Alia Putri, Denny Lyus Sihite, Ajeng Tias Endarti, Sutanto Priyo Hastono, Hasnawati Amqam. Analysis of the Relationship of Noise Exposure and Hearing Loss in PPSU Workers in North Jakarta. Science Journal of Public Health.

Vol. 6, No. 5, 2018, pp. 140-144. doi: 10.11648/j.sjph.20180605.14

Received: November 5, 2018; Accepted: November 22, 2018; Published: December 6, 2018

\begin{abstract}
Hearing loss is one of the many health problems experienced by workers in high noise exposure areas. The purpose of this study was to analyze the relationship between noise intensity and hearing loss in PPSU workers in North Jakarta. This type of research is quantitative analytic using cross-sectional design involving 45 PPSU workers in North Jakarta. Hearing loss was identified by audiometric examination with air conditioning (AC), while noise intensity in the worker's area was measured using a sound level meter. The results of this study showed that $60 \%$ of respondents experienced hearing loss, and $51.1 \%$ of the areas had noise intensity $\geq 75 \mathrm{~dB}$. The results of categorical analysis showed that there is a relationship between noise intensity and hearing loss with prevalence of ratio was 5.2. Logistic regression analysis showed that respondents who work in areas with noise intensity $\geq 75 \mathrm{~dB}$ had the opportunity 7 times to experience hearing loss after being controlled by variable smoking behavior, and hobbies towards noise. Exposure to high noise is something that cannot be avoided by PPSU workers, therefore to reduce or prevent the occurrence of hearing loss, the workers should use earplugs while working, and should reduce smoking and listening music with earphones. In addition, the workers should conduct regular audiometric examinations and attend health counseling at the workplace.
\end{abstract}

Keywords: Hearing Loss, Audiometry, Noise

\section{Introduction}

One of the most common occupational disease is hearing loss. Hearing loss is the disturbing and discomfort felt by individual without medically considering the pathologic aspect [1]. Human ear can only receives noise with intensity $85 \mathrm{~dB}$ (A) (safe limit) and with frequency 20 up to $20.000 \mathrm{~Hz}$ [2]. The highest limit of intensity is $140 \mathrm{~dB}(\mathrm{~A})$ whereas if someone listens to the noise, it will cause pain and trigger hearing loss and increase in hearing threshold [3].

According to WHO, it was estimated that 360 (91\%) million population in the world suffered from hearing loss, whereas among them were adult (183 million male and 145 million female) and $32(9 \%)$ million were children. It was also estimated that $75-140$ million of them comes from South East Asia [4].

Workplace Safety and Report (2016) in Singapore showed that in $2014-2015$, noise induced hearing loss was the disease with the highest number of sufferers with 594 workers in 2014 and 498 workers in 2015. The second highest was the musculoskeletal disorder with the number of sufferers in 2014 were 315 workers and in 2015 were 304 workers. The third highest were skin diseases with the number of sufferers were 54 workers in 2014 and 89 workers in 2015 [5].

In Indonesia, the result of National Health Survey of Sight and Hearing Sense that were done in 7 provinces showed that 
the prevalence of deafness in Indonesia was $0,4 \%$ and hearing loss was $16,8 \%$, with the main etiology of hearing loss were middle ear infection $(3,1 \%)$, presbycusis $(2,6 \%)$, ototoxic induced hearing loss $(0,3 \%)$, congenital hearing loss $(0,1 \%)$ and noise induced hearing loss [6].

According to study done by Listianingrum (2017) to Supeltas Traffic Operation Volunteers members in Surakarta City showed that 41 workers $(87,2 \%)$ out of 47 workers suffered from hearing loss [7].

Petugas Penanganan Prasarana dan Sarana Umum (PPSU) are workers handling the public facilities and infrastructure within a certain period of time according to Letter of Assignment. The working scope of PPSU includes handling street facilities and infrastructure, park, drainage system, hygiene facilities and public lighting [8].

There is physical danger such as noise in the working environment of PPSU workers. The activity of PPSU workers located in the main road, where there are either two, three or four-wheeled vehicles that passes and can cause noise in the workplace. Moreover, there are working activities that result in high noise such as cutting grass and trees. The noise resulted from machine is higher compare to noise from the main road [9]. The noise can influence the health of ears of PPSU workers. The higher the intensity of the noise is, the higher the risk of PPSU to suffer from hearing loss.

Basically the higher the intensity of noise a person receives, the greater the risk of being affected by noise. High noise intensity can have a direct impact on the health of someone even directly can damage the senses of people hearing. This is one of the risk factors for hearing loss.

Based on the results of audiometry examination obtained from the Head Office of HIPERKES and Occupational Safety of the Department of Manpower and Transmigration of DKI Jakarta against 791 PPSU workers in the North Jakarta area in 2017 shows $51.8 \%$ of workers had hearing loss in the right ear and $56.8 \%$ of workers experienced hearing loss in left ear. Meanwhile, the result of an audiometric examination of 91 PPSU workers in the working area of Kelapa Gading SubDistrict in North Jakarta in 2017 found that as many as $40.6 \%$ of workers experienced hearing loss in the right ear and $47.2 \%$ of workers experienced hearing loss in the left ear.

According to the above studies, a preceding study to analyze the relationship between noise exposure and hearing loss in PPSU workers in North Jakarta were done. It was hoped that this study would results in recommendations on preventive efforts to reduce and prevent hearing loss in PPSU workers in North Jakarta.

\section{Method}

This study was a quantitative research using cross sectional approach. The study was done to PPSU workers of Main Office of Industrial Hygiene and Occupational Safety in Kelapa Gading District, North Jakarta, on April-June 2018. This study involved 45 PPSU workers using incidental sampling method.

The data collection technique was done by measuring and interview. Variable of hearing loss as dependent variable was measured using audiometry on the left and right ear. While noise exposure was measured using sound level meter as noise intensity. In addition, there were confounding variables such as age, working period, history of ear disease, smoking habit, and hobby towards noise that was taken through interview to PPSU workers using questionnaire as a guide.

Data analysis using Chi Square and logistic regression analysis was aimed to test the relationship between noise exposure with hearing loss and age, working period, history of ear disease, smoking habit and hobby towards noise as confounding variables.

\section{Result and Discussion}

\subsection{Result}

The results of the descriptive analysis in Figure 1 shows there were $60 \%$ experienced hearing loss. Most respondents exposed to noise $\geq 75 \mathrm{~dB}(\mathrm{~A})(51.1 \%)$, then $57.8 \%$ age $\leq 30$ years old, $57.8 \%$ had working period $\leq 2$ years, $68.9 \%$ having a history of ear disease, $71.1 \%$ smoking behavior, and $68.9 \%$ having hobbies towards noise.

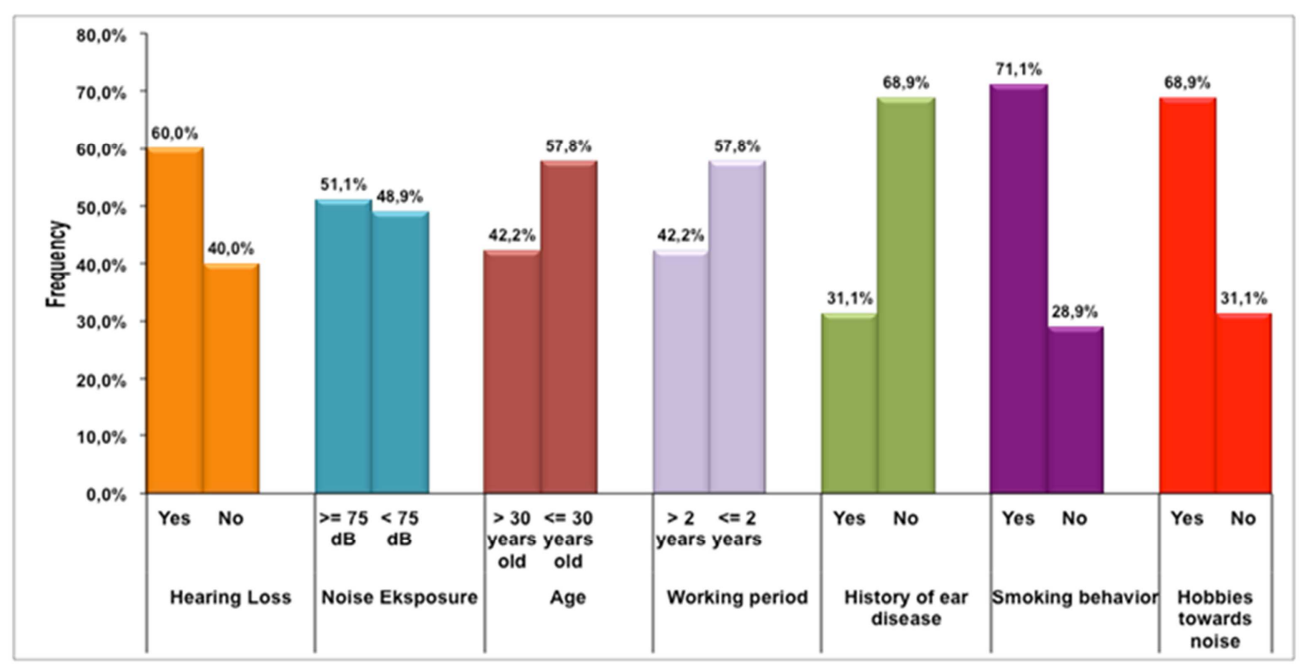

Figure 1. Description of Hearing loss, Noise Exposure, Age, Working period, History of Ear Disease, Smoking Behavior, and Hobbies Toward Niose. 
The result of analysis in table 1 shows that there were $60 \%$ PPSU workers suffers from hearing loss whereas among them, $78.3 \%$ was exposed to noise $\geq 75 \mathrm{~dB}, 78.9 \%$ age $>30$ years old, $73.7 \%$ had working period $>2$ years, $85.7 \%$ had history of ear disease, $75 \%$ had smoking habit, $77.4 \%$ had hobby towards noise. There was a significant correlation between noise exposure and hearing lose $(\mathrm{Pv}=0.024)$. For some counfounding variables, including age, history of ear disease, smoking behavior, and hobbies toward noise has correlation with hearing loss with each $P$ value of $0.05,0.042,0.004$, and 0.001 . While the working period did not show a significant correlation with the hearing loss $(\mathrm{Pv}>0.05)$.

Table 1. Analysis Result of Hearing Loss according to noise exposure, age, working period, history of ear disease, smoking behavior, and hobby towards noise of PPSU workers in North.

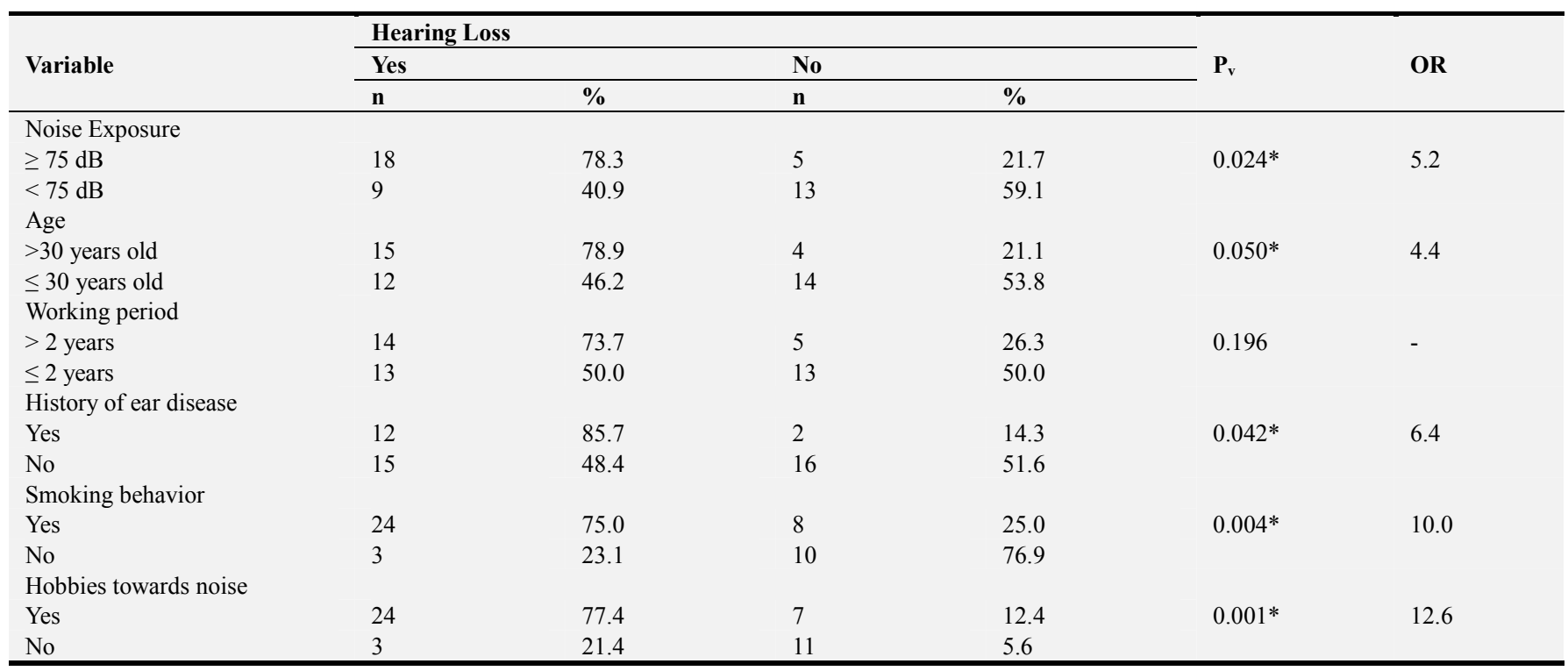

*variables is significant

The result of analysis of the relationship shows that noise exposure as the main variables has correlation with hearing loss with the OR value of 5.2. The confounding variables that are age $(\mathrm{OR}=4.4)$, history of ear disease $(\mathrm{OR}=6.4)$, smoking habit $(\mathrm{OR}=10.0)$ and hobby towards noise $(\mathrm{OR}=12.6)$ shows a significant relationship with hearing loss.

Table 2 shows the result of multivariate analysis using logistic regression test. The test shows that workers exposed to noise $\geq 75 \mathrm{~dB}$, has 7 times higher chance to suffer from ear disorders compare to workers exposed to noise $<75 \mathrm{~dB}$ after controlled by factors such as smoking behavior and hobby toward noise.

Table 2. Result of Logistic Regression Test.

\begin{tabular}{llll}
\hline Variable & B & Wald & P value \\
\hline Noise Exposure & 1.934 & 3.609 & 0.050 \\
Smoking Habit & 2.572 & 4.942 & 0.026 \\
Hobby toward noise & 2.445 & 5.080 & 0.024 \\
Constant & -4.528 & 8.128 & 0.004 \\
\hline
\end{tabular}

\subsection{Discussion}

According to study showing the relationship between noise exposures with hearing loss, most workers exposed to noise $\geq$ $75 \mathrm{~dB}(\mathrm{~A})$ had tendency to suffer from hearing loss. The result of bivariate analysis shows that there was a significant correlation between noise expposure and hearing loss in PPSU Workers. Someone who exposed to noise $\geq 75 \mathrm{~dB}(\mathrm{~A})$ were at a risk of 5.2 times greater for hearing loss if compared to workers who are exposed to noise $<75 \mathrm{~dB}(\mathrm{~A})$.

This study is in agreement with a study done by Listianingrum to Supeltas Traffic Manager Volunteers members and Marlina et, all to PT. X workers which showed that noise intensity had correlation with hearing loss with the p-value of 0.005 and $0.0001[7,10]$.

Noise induces damage in the inner ear. The lesion is varied, such as dissociation of organ of corti, rupture of the membrane and changes of stereosilia and subcellular organelle. Soetirto stated that hearing loss can be caused by continuous and long duration exposure from micro noise (60$70 \mathrm{~dB}(\mathrm{~A}))$. Exposed to noise with intensity $85 \mathrm{~dB}$ (A) or more can result in damage of receptors of organ of corti in the inner ear. The damage is most likely in the receptors of noise with frequency $3000 \mathrm{Hertz}(\mathrm{Hz})$ up to $6000 \mathrm{~Hz}$, and the most damage is in receptor for noise with frequency of 4000 Hz. There are many factors contributing to likelihood of someone to suffer from noise-induced hearing loss such as higher intensity noise, higher frequency noise and longer exposure to noise [11].

Smoking habit also shows significant relationship with hearing loss. As many as $71.1 \%$ of PPSU officers in the Kelapa Gading District of North Jakarta who have smoking behavior and $28.9 \%$ who do not have smoking behavior. The results of the bivariate analysis found that $75 \%$ of workers who had a smoking habit experienced hearing loss. Someone who have a smoking behavior will have a 10 times greater chance of hearing loss compared to workers who do not have 
smoking behavior. According to logistic regression result, smoking habit is the confounding variable that influences the relationship between noise exposure and hearing loss.

This result was in agreement with a study done in a company and in a district hospital in Surakarta, Center Java which stated that smoking habits had correlation with hearing loss with the p-value of 0.007 . Smoking habit will increase the chance of hearing loss if exposed to noise [12]. Smoking habit will increase the chance of hearing loss if exposed to noise

The above statement can happen because nicotine and carbon monoxide from cigarette smoking can presses the blood vessels. This restriction process may decrease the oxygen flow in the inner ear thus the hair cells in cochlea which responsible to translate sound vibration to impulse carried to the brain will be disturbed due to hypoxia [12].

Nicotine content can also cause disturbances of neurotransmitter in auditory nerves thus making it unable to accurately identify which type of sound that is being sent to the brain. Free radicals in the tissues and hair cells will result in permanent damage of the inner ear [13].

Until now, it has been reported that the mechanism of hearing loss due to noise includes distortion and loss of normal structure due to damage to stereosilia after exposure to noise, and damage to the hair cells of Corti's organs due to DNA damage (due to increased levels of toxic free radicals and reactive oxygen species produced during exposure to noise), lipid and protein degradation and acceleration of apoptosis. The mechanism of smoking affects the hearing organs including direct ototoxicity of nicotine and cochlear ischemia due to increased carboxy hemoglobin levels, vasoconstriction, and increased blood viscosity due to smoking.

In addition, it is also characterized by reduced blood supply to the cochlea from a single blood vessel and lack of collateral circulation. This is also characterized by very high metabolic activity of hair cells. Therefore, it is very susceptible to ischemic injury. Based on this, smokers who work in noisy workplaces will be more susceptible to hearing loss than non-smokers due to the complex involvement of this mechanism [6].

The proceeding content of this study shows that hobby towards noise is also factor related to hearing loss. Hobbies or habits contribute to hearing. Hobbies related to noise or work habits that increase noise exposure will affect or increase the risk of workers experiencing hearing loss. The types of hobbies in question are listening to music, karouke, clubbing, shooting, and watching movies. And also other hobbies that can cause hearing problems such as diving.

As many as $68.9 \%$ of PPSU officers in the Kelapa Gading District of North Jakarta who have hobbies toward niose and $31.1 \%$ who do not have noisy hobbies toward niose. The results of the bivariate analysis found that $77.4 \%$ of workers who had noisy hobbies had hearing loss $(\mathrm{Pv}=0.001)$. A person who has a hobby related to noise will be at risk 12.6 times more likely to experience hearing loss than those who do not have a hobby related to noise. Hobby toward noise was a confounding variable that influence the relationship between noise exposure and hearing loss.

A study done by Akbar in 2012 showed that in a production company, workers that had hobby toward noise had 2 times higher chance to suffer from hearing loss. Hobby toward noise will increase the chance of hearing loss when exposed to noise [14].

According to field interview, most workers had hobby toward noise, among them were 29 workers who prefer listening to music using earphone and speaker $(93,5 \%)$ and 2 workers prefer to do karaoke $(6,5 \%)$. Such hobbies may increase their exposure to noise. If workers often exposes to noise during work, thus hobby toward noise may increase the chances of hearing loss.

Related to the frequency of listening to music using headset, in a study done by Vogel (2009), stated that listening to music has close relationship with risky behaviors compare to protective behavior to induce hearing loss [6].

\section{Conclusion and Recommendation}

Hearing loss that occurred in PPSU Workers in the Kelapa Gading District of North Jakarta was $66.7 \%$ and $78.3 \%$ of them were exposed by noise $\geq 75 \mathrm{~dB}$ (A). Respondent of this study were dominated by workers aged $\leq 30$ years $(57.8 \%)$, had a working period $\leq 2$ years (57.8\%), had a history of ear disease $(68.9 \%)$, had a smoking habit $(71.1 \%)$, and had a hobby towards noise $(68.9 \%)$. There is a relationship between noise exposure, age, history of ear disease, smoking behavior, and hobbies for noise with hearing loss.

Exposure to noise during work is main factor that result in hearing loss in PPSU workers in North Jakarta. The severity of hearing loss will be higher if there are smoking habit and hobbies toward noise such as listening to music using earphone/headset or loudspeaker and karaoke with loud music. Workers who work in area with noise $\geq 75 \mathrm{~dB}$ have seven times higher chances for hearing loss, moreover with smoking habit and listening to loud music.

Education about the danger of noise and its impact to health of ear should be more intensively done in workplace. Counseling to use self-protection device should be improved by installing media and poster in certain area in workplace that can be easily seen by workers. Furthermore, the use of work policy on sanction to workers that does not use selfprotection device should be more emphasized.

\section{References}

[1] Pawlazyk-Luszeznska, M., et al. 2013. Noise Induced Hearing Loss Research In Central Eastern And Sound Eastern Europe And Newly Independent Status. Noise \& Health.

[2] Chandra, Budiman. 2007. Pengantar Kesehatan Lingkungan. Jakarta: Penerbit Buku Kedokteran EGC.

[3] Utamiati, Ami. 2012. Effects of Noise on Hearing Disorders in Rice Refinery Employees in Sidoarjo II Ramunia. Thesis. Faculty of Medical North Sumatera University. Medan. 
[4] Ministry of Health. 2014. Indonesian Health Profile in 2014. http://www.depkes.go.id/resources/download/pusdatin/profilk esehatanindonesia/profil-kesehatan-indonesia-2014.pdf.

[5] Ministry of Manpower. 2016. Workplace Safety and Health: Occupational Disease in Singapore. https://www.wshinstitute.sg/files/wshi/upload/event/file/Occu pational $\% 20$ diseases $\% 20$ in $\% 20$ SG$\% 20$ What $\% 20$ Else $\% 20$ Needs\%20to\%20Be\%20Done.pdf.

[6] Rahmawati, Fitri Nur. 2016. Relationship between Noise Intensity and Decrease in Hearing Power Manpower Production Section at PT Wijaya Karya Beton Tbk PPB Majalengka. Thesis. Faculty of Public Health Muhamadiyah Surakarta University.

[7] Listianingrum, Daranita Aprilia. 2017. Effect of Traffic Noise on Hearing Loss in Supeltas in Surakarta City. Thesis. Faculty of Public Health Muhamadiyah Surakarta University.

[8] Peraturan Gubernur Provinsi Daerah Khusus Ibukota Jakarta Nomor 7 Tahun 2017 Penanganan Prasarana dan Sarana Umum Tingkat Kelurahan. 16 Januari 2017. Gubernur Provinsi Daerah Ibukota Jakarta.

[9] Djaja, I Made, Ikron, Wula ndari, Ririn A. 2007. Effect of Road Traffic Noise on Psychological Health Disorders of Children in SDN Cipinang Muara, Jatinegara District, East Jakarta City, DKI Jakarta Province, 2005. Journal of the
Environmental Health. Faculty of Public Health Indonesia University 11(1): 32-37.

[10] Marlina, S., Suwondo, Jayanti. 2016. Risk Factor Analysis of Sensorineural Hearing Disorders in PT. X Semarang. Journal of Health. Vol. 4. No. 1 Januari 2016: 2356-3346.

[11] Sutopo, M., dkk. 2007. Relationship Between Flight Activity Noise Intensity at Adi Sucipto Airport and Hearing Threshold Value in Children. Public Medical Journal, Vol. 23(No. 1), 1220 .

[12] Safitri, Ana. 2017. The relationship between the frequency of smoking and hearing loss in Dr. Moewardi. Thesis. Faculty of Medical Muhammadiyah Surakarta University.

[13] Kusumawati, Indah. 2012. Relationship of Noise Levels in the work environment with the incidence of hearing loss in workers at PT. X in 2012. Thesis. Faculty of Public Health Indonesia University. Depok.

[14] Akbar, Rizuli. 2012. Analysis of the Relationship between Noise Exposure Doses and Equivalent L Approach and Decreasing Hearing Workers in PT Master Wovenindo Label Production Division in 2011. Thesis. Faculty of Public Health Indonesia University. Depok. 